\title{
Extinctions of North American Fishes During the Past Century
}

\author{
Robert R. Miller, James D. Williams, and Jack E. Williams
}

\begin{abstract}
Extinctions of 3 genera, 27 species, and 13 subspecies of fishes from North America are documented during the past 100 years. Extinctions are recorded from all areas except northern Canada and Alaska. Regions suffering the greatest loss are the Great Lakes, Great Basin, Rio Grande, Valley of Mexico, and Parras Valley in Mexico. More than one factor contributed to the decline and extinction of $82 \%$ of the fishes. Physical habitat alteration was the most frequently cited causal factor $(73 \%)$. Detrimental effects of introduced species also were cited in $68 \%$ of the extinctions. Chemical habitat alteration (including pollution) and hybridization each were cited in $38 \%$ of the extinctions, and overharvesting adversely affected $15 \%$ of the fishes. This unfortunate and unprecedented rate of loss of the fishery resource is expected to increase as more of the native fauna of North America becomes endangered or threatened.
\end{abstract}

\section{RESUMEN}

Durante los 100 años pasados se registraron extinciones de tres generos, 27 especies, y 13 subespecies de peces en Norte America. Extinciones fueron registrados de todas partes fuera de la parte norte de Canada y Alaska. Las regiones que sufrieron las pérdidas mas grandes fueron los Lagos Grandes (E.U. y Canada), el Bolsón Grande, Río Bravo, Valle de México, y el Valle de Parras de México. Mas de un factor contribuyó a $82 \%$ de las extinciones. Alteración física del habitat fue el factor causal citada con mayor frecuencia $(73 \%)$. Efectos dañosos de introducciones de especies exóticas tambien fueron citados como factores contribuyentes en una mayoría de las extinciones (68\%). Ambas alteración quimica del habitat (incluyendo la contaminación) e hibridación fueron citadas en $38 \%$ de las extinciones, y sobre explotación afectó adversamente a $15 \%$ de las especies extinctas. Se espera que esta desafortunada, y anteriormente desconocida, tasa de extinción se aumentará aún mas mientras mayor parte de la fauna nativa de Norte America llega a encontrarse en peligro, o en amenaza, de extinción.

M any rivers, lakes, and springs in North America have been fragmented, polluted, or destroyed. These losses have been documented through growing lists of endangered fishes (Deacon et al. 1979; Campbell 1985, 1988; USDI 1989) and endangered ecosystems (Williams et al. 1985). The American Fisheries Society now lists 103 fish taxa as endangered, 114 as threatened, and 147 others as of special concern in North America (Williams et al. 1989, this issue).

Despite the increasing threat to the aquatic resources, extinctions have been poorly documented. Part of the problem is the difficulty in determining when a species is extinct (Diamond 1987). Should a species be considered extinct when it is not found in a single survey, or are many more negative searches required before extinction should be considered confirmed? Extinctions are particularly hard to document for small fishes or species that easily evade casual observation or occupy habitats that are difficult to sample.

Some taxa may persist at perilously low numbers for many years, only to be rediscovered in remote corners of their habitats or after populations have recovered sufficiently to again be noticed. There are several examples of

Robert R. Miller is curator emeritus of fishes at the Museum of Zoology, University of Michigan, Ann Arbor, MI 48109. His career in the study of fishes from western United States, Mexico, and Guatemala spans more than 5 decades. James $D$. Williams conducts research on endangered and threatened fishes, and impacts of exotic species on native fishes at the Fish and Wildife Service, National Fisheries Research Center in Gainesville, FL. Jack E. Williams conducted research on endangered fishes for the Fish and Wildlife Service and the University of California at Davis. He is currently fisheries program manager for the Bureau of Land Management. All three authors have served as chairman of the AFS Endangered Species Committee. The present paper is part of a monograph on extinct fishes in preparation by the authors.

fishes that were considered to be extinct only to be rediscovered by surprised scientists. The Owens pupfish (Cyprinodon radiosus) was rediscovered in a remote corner of Fish Slough, California, in 1964 (Miller and Pister 1971) after being presumed extinct by Miller (1961) and others. Similarly, the Shoshone pupfish (C. nevadensis shoshone) was rediscovered in 1986 after numerous surveys failed to find a population that had dwindled to such a small size that the remaining individuals experienced a genetic bottleneck (Taylor et al. 1988). For such endangered species where remnant populations survive, much of the original genetic variation has been lost (Wilson 1988). Unfortunately, chances of rediscovery are past for an increasing number of fishes.

Our purposes here are to provide a comprehensive list of recently extinct fishes of the North American continent and detailed accounts of each extinction. We include fishes where extinctions are presumed on the basis of numerous negative surveys and those taxa that are poorly known but where extinction is presumed and rediscovery 


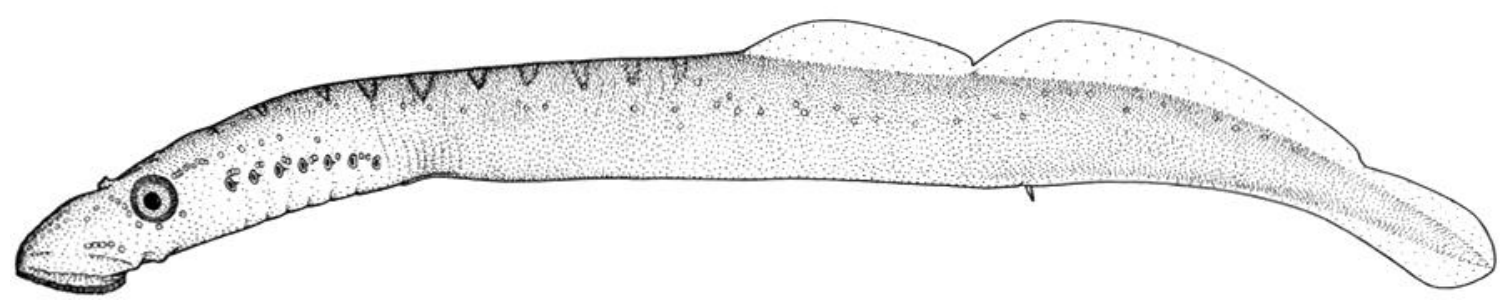

Figure 1. Miller Lake lamprey, Lampetra minima. An adult male collected near the northern shore of Miller Lake, Klamath County, Oregon, 17 July 1952. Drawing by Sara V. Fink.

appears impossible. All fish extinctions suspected to have occurred during the past 100 years are included.

\section{The Extinct Fishes}

Miller Lake Lamprey Lampetra minima Bond and Kan Figure 1

This dwarf species of parasitic lamprey was endemic to Miller Lake, Klamath County, Oregon (Bond and Kan 1973). It is thought to have evolved from a stock of the Pacific lamprey ( $L$. tridentata) isolated in Miller Lake after the explosion of Mt. Mazama (now Crater Lake), which probably destroyed virtually all aquatic life in the area 6,600 years ago. Kan and Bond (1981) attributed evolution of this unique species to a reduced food supply, short generation time, and the small numbers of lampreys surviving in the area after the mountain's eruption.

Forty-five adult specimens examined by Bond and Kan (1973) ranged from 72 to $129 \mathrm{~mm} \mathrm{TL}$, making this the smallest species of parasitic lamprey known. In addition to its small size, the species was notable in having relatively high fecundity, indicating a greater use of energy for gamete production than for spawning migrations (Kan and Bond 1981).

Because it preyed on introduced trout, the Miller Lake lamprey was purposely poisoned with ichthyocides during the 1950 s by the state of Oregon. The last collection of the species was made from Miller Lake on 17 July 1952. Subsequent investigations have confirmed the extinction of this species.

\section{Longjaw Cisco Coregonus alpenae (Koelz)}

The longjaw cisco, described from Lake Michigan off Charlevoix, Michi- gan, was most abundant in Lakes Michigan and Huron. The species was rare in Lake Erie, where the last record of capture was in November 1957 (Scott and Smith 1962). It was one of the largest ciscoes in the Great Lakes; adults often attained a length of $38 \mathrm{~cm}$ and a weight of $1 \mathrm{~kg}$ (Koelz 1929).

Stocks of this large and commercially valuable species were severely depleted by overfishing in Lakes Michigan and Huron by the turn of the century (Smith 1968). As the catches began to decrease, the fishery became more intense and selective. The severe decline caused by commercial overexploitation probably was aided in its later stages by predation from the exotic sea lamprey (Petromyzon marinus), which became established in the 1940s. As the longjaw cisco became increasingly rare, it is believed to have become extinct through hybridization with more common ciscoes (G. R. Smith, University of Michigan, personal communication). The last known record of capture in Lake Michigan was from Grand Traverse Bay in 1967 and in Lake Huron from Georgian Bay, Ontario, on 12 June 1975 (T. N. Todd, Fish and Wildlife Service, Ann Arbor, MI, personal communication).

\section{Deepwater Cisco Coregonus johannae (Wagner)}

The deepwater cisco was one of the two most important species in the early cisco fisheries of the Great Lakes. The deepwater cisco occurred in the deeper parts of Lakes Michigan and Huron, at depths of 55 to $183 \mathrm{~m}$ (Koelz 1929). The last known record of capture for the species in Lake Michigan was from Grand Traverse Bay in June 1951, and in Lake Huron from Wolfsell, Ontario, on 4 August 1952 (T. N. Todd, Fish and Wildlife Service, Ann Arbor, MI, personal communication).

Heavy exploitation from the commercial fishery produced a marked decline in deepwater cisco populations during the early 1900s (Smith 1970). Continued intensive fishing for all larger ciscoes, coupled with predation by exotic sea lampreys, led to dwindling stocks of this species (Smith 1964). As populations of the deepwater cisco were diminished, introgressive hybridization with more common ciscoes may have contributed to final extinction.

\section{Lake Ontario Kiyi Coregonus kiyi orientalis Koelz}

In his monograph on coregonid fishes of the Great Lakes, Koelz (1929) recognized the kiyi of Lake Ontario as a distinct subspecies (Coregonus kiyi orientalis). It was one of the smallest ciscoes in the Great Lakes and occurred throughout Lake Ontario at depths of 37 to $137 \mathrm{~m}$ (Koelz 1929).

Along with other ciscoes, the Lake Ontario kiyi supported an important commercial fishery from the 1800 s through the 1930s. Although fishery statistics did not distinguish among the species, the Lake Ontario kiyi was probably the most important species in the Lake Ontario fishery (Pritchard 1931).

The last known collection of this fish was made on 19 September 1964 near Oswego, New York (T. N. Todd, Fish and Wildlife Service, Ann Arbor, MI, personal communication). Like the other extinct coregonid fishes of the Great Lakes, the decline and ultimate disappearance of the Lake Ontario kiyi was caused by a combination of events. Overfishing was a major factor. Establishment of exotic and non-native fishes and deterioration of water quality from eutrophication and release of toxic chemicals also were contributing factors. 


\section{Blackfin Cisco \\ Coregonus nigripinnis (Gill)}

The blackfin cisco was one of the largest and most commercially valuable of the coregonid fishes in the Great Lakes. It occurred in the deeper waters (110 to $146 \mathrm{~m}$ ) of Lakes Michigan and Huron (Koelz 1929).

The decline and eventual extinction of the blackfin cisco were caused by the same factors (overfishing, sea lamprey predation, and introgressive hybridization) as those described for the longjaw cisco. The last blackfin cisco known from Lake Huron was taken at Wiarton, Ontario, on 26 June 1923 (Koelz 1929). The last record of the species from Lake Michigan was on 26 November 1969 at Marinette, Wisconsin (T. N. Todd, Fish and Wildlife Service, Ann Arbor, MI, personal communication).

\section{Yellowfin Cutthroat Trout Oncorhynchus clarki macdonaldi (Jordan and Evermann)}

The yellowfin cutthroat trout was known only from Twin Lakes on Lake Creek, a tributary to the Arkansas River in Lake County, Colorado. The presence of the greenback cutthroat trout (O. clarki stomias) in Twin Lakes and its early extinction clouded the taxonomic history of the yellowfin cutthroat trout. Behnke (1979) examined yellowfin and greenback cutthroat trouts of the same size from Twin Lakes and concluded that macdonald $i$ was a valid taxon, probably most closely related to the Colorado cutthroat trout (O. c. pleuriticus):

Apparently a favorite of local anglers during the late $1800 \mathrm{~s}$, the yellowfin cutthroat attained a weight of at least $5 \mathrm{~kg}$ (Jordan 1922). Yellowfin cutthroat trout were propagated at Leadville $\mathrm{Na-}$ tional Fish Hatchery and may have been introduced into Colorado's Grand Mesa (Behnke 1979) and even into France (Jordan 1922). Attempts at establishment and long-term propagation failed.

Non-native trouts were extensively introduced into Twin Lakes and landlocked salmon (Salmo salar sebago), rainbow trout (Oncorhynchus mykiss), lake trout (Salvelinus namaycush), and brook trout (S. fontinalis) all were established in the lakes by the turn of the century (Juday 1907). Introgressive hybridization with rainbow trout and competition from deep-water lake trout apparently eliminated yellowfin cutthroat trout as well as the local population of greenback cutthroat trout from Twin Lakes around 1910. The Forest Service apparently propagated a silvery "yellowfin" trout from Island Lake, Colorado, during the early 1930 s, but their genetic purity was doubtful.

\section{Alvord Cutthroat Trout Oncorhynchus clarki ssp. Figure 2}

The Alvord cutthroat trout was endemic to streams in the Alvord Basin of southeastern Oregon and northwestern Nevada. It was known only from Trout Creek in Oregon and Virgin Creek in Nevada, although it may have lived in several of the larger Alvord Basin streams during recent times (Hubbs and Miller 1948). The Alvord cutthroat's nearest relative appears to be another undescribed subspecies of cutthroat trout from Willow and Whitehorse creeks in Oregon, just east of the Alvord Basin.

Hybridization and introgression with introduced rainbow trout apparently caused extinction of the Alvord cutthroat trout. Rainbow trout characteristics were already noticeable in the first collection of trout from Virgin Creek made by Carl L. Hubbs and family in 1934. Cutthroat trout pigmentation was present in Trout Creek fish collected by Carl E. Bond in 1953 and 1957, but no basibranchial teeth (typically present in O. clarki) were found (C. E. Bond, Oregon State University, personal communication; Williams and Bond 1983). Although no collections of trout from Virgin Creek are known from 1957 to 1970 , specimens collected in 1971, 1978, and 1979 showed typical rainbow trout characteristics or appeared to be rainbow $x$ cutthroat hybrids (Williams and Bond 1983). Electrophoretic analyses of trout collected from isolated portions of Virgin Creek in 1984 to 1986 showed large portions of rainbow trout alleles in all samples (Tol and French 1988). Genetically pure Alvord cutthroat trout appear to be extinct, and may have been extirpated soon after stockings of rainbow trout during the early 1930s.

\section{Silver Trout \\ Salvelinus agassizi (Garman) Figure 3}

The silver trout from Dublin Pond, New Hampshire, was recognized as a unique, distinctive trout as early as 1849 (Bigelow 1850), although it was not formally described as a new species

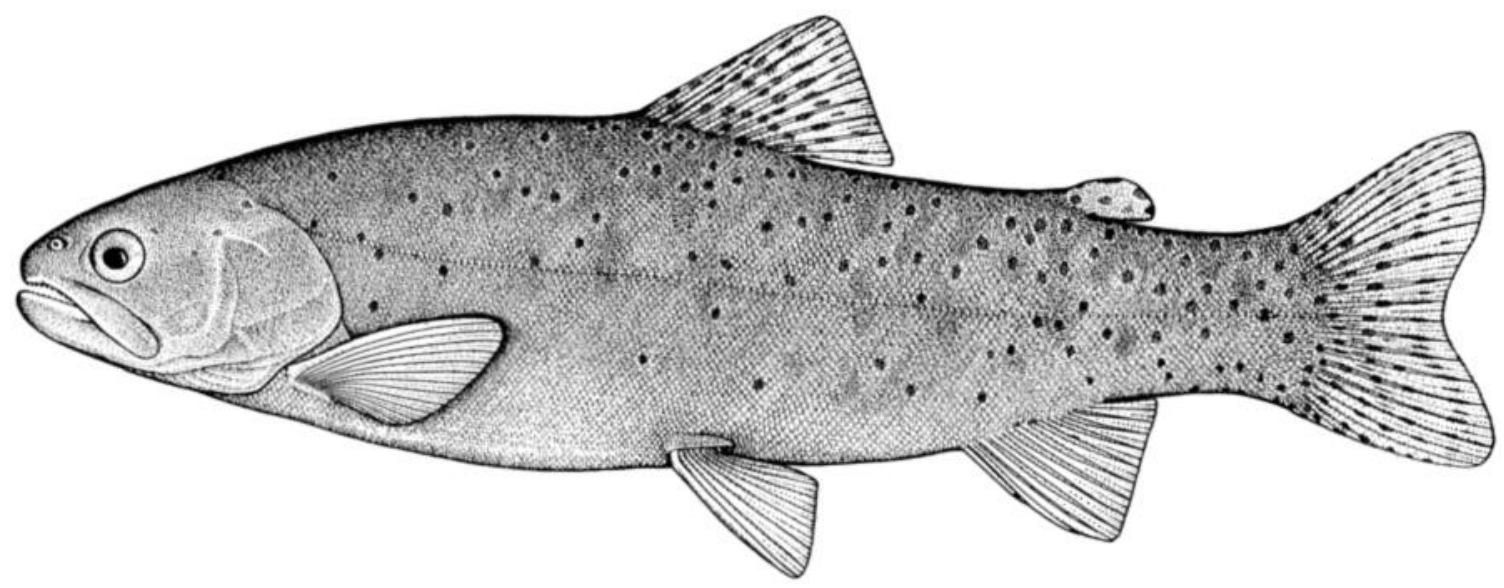

Figure 2. Alvord cutthroat trout, Oncorhynchus clarki ssp. An adult female, $106.5 \mathrm{~mm}$ SL, collected from Virgin Creek, Humboldt County, Nevada. Drawing by Sara V. Fink. 


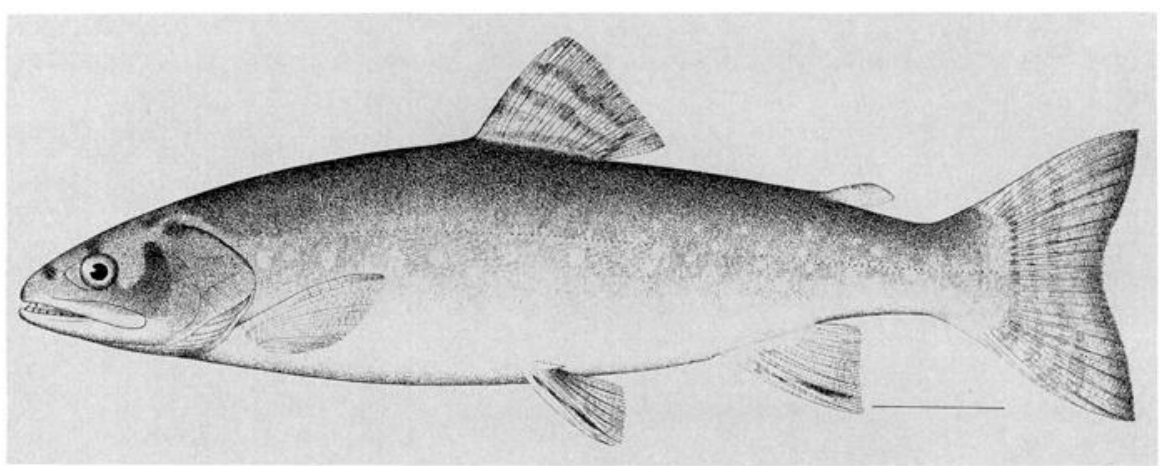

Figure 3. Silver trout, Salvelinus agassizi. A specimen $21.6 \mathrm{~cm}$ TL collected from Monadnock Lake, Cheshire County, New Hampshire, 2 December 1887. Drawing by Sherman F. Denton.

until 1885. In addition to Dublin Pond (also called Center Pond or Monadnock Lake), silver trout occurred in Christine Lake (Warfel et al. 1939). Both were in the Connecticut River drainage. Morphologically, silver trout are similar to brook trout, but the two are distinctly different in coloration. Both species occurred sympatrically, and the silver trout was relegated by many early workers to subspecific status, Salvelinus fontinalis agassizi (Jordan 1885).

Adult silver trout typically weighed between 1 and $2 \mathrm{~kg}$, but individuals up to $3 \mathrm{~kg}$ were known (Kendall 1914). They were taken by fishermen using a variety of baits, including worms, minnows, grasshoppers, and artificial flies.

The species began to decline in abundance during the late 1800 s. This decline appears to be attributable to overharvesting during spring and autumn, when silver trout were in shallow water. Although populations were reduced by excessive fishing, it was the introduction of non-native fishes that caused extinction of the species. Warfel et al. (1939) reported the following introduced fishes in Dublin Pond: Atlantic salmon, rainbow trout, lake trout, chinook salmon, rainbow smelt (Osmerus mordax), brown bullhead (Ictalurus nebulosus), yellow perch (Perca flavescens), and white perch (Morone americana). Both Dublin Pond and Christine Lake received hatchery stocks of brown trout in addition to the native form. Hybridization with hatcheryreared brook trout may have contributed to extinction of the silver trout. The last record of silver trout from Christine Lake was in 1926 (Warfel et al. 1939) and from Dublin Pond in 1930 (Behnke 1980).
Hubbs (1940) described the Maravillas red shiner from two localities in the Big Bend region of Texas. The type series consists of two collections of 41 specimens taken from Garden Springs on 16 April 1937 and 19 July 1938, and one collection of 10 specimens from Peña Colorado Creek taken on 16 April 1937. Both localities are in the Maravillas Creek drainage, tributary to the Rio Grande. The last known collection of this subspecies was apparently made by Clark Hubbs in 1954, when red shiners were collected from upper Maravillas Creek at its confluence with Peña Colorado Creek.

By 1954, Garden Springs was dominated by an introduced population of plains killifish (Fundulus zebrinus) and no red shiners could be found (Matthews 1987). Matthews (1987) suggested that the subspecies was extinct because of loss of the Garden Springs population and unsuccessful efforts to collect the shiner from Peña Colorado Creek in 1978.

\section{Mexican Dace Evarra spp.}

The Mexican cyprinid genus Evarra was described by Woolman (1895) from canals in the endorheic Valley of Mexico, where Mexico City and its suburbs name meaning "maker of gods in lands beyond the sea" (Jordan and Evermann 1896-1900), includes three species: $E$. eigenmanni Woolman, E. tlahuacensis Meek, and E. bustamantei Navarro.

Unfortunately, relatively few museum specimens of these small (max-

\section{Maravillas Red Shiner Cyprinella lutrensis blairi (Hubbs)} now stand. The genus Evarra, an Indian

imum SL $=80 \mathrm{~mm}$ ) minnows still exist. Alvarez and Navarro (1957) had large series of two of the species, but these have largely disappeared. Evarra is presumed to be derived from the Mexican genus Algansea (Barbour and Miller 1978).

Alvarez and Navarro (1957) believed all three species to be nearing extinction three decades ago, and all were believed to be extinct by 1983 (E. DiazPardo, Instituto Politecnico Nacional, Mexico City, personal communication). The extinctions coincided with drying of the lakes, spring-fed ponds, and canals of the valley floor, due to agricultural practices, persistent groundwater removal, and the development of Mexico City and suburbs.

\section{Independence Valley Tui Chub Gila bicolor isolata Hubbs and Miller}

Gila bicolor isolata was endemic to Warm Springs of Independence Valley in Elko County, Nevada. It was quite possibly extinct by the time it was originally diagnosed as a new subspecies by Hubbs and Miller (1972). In the first collection of the subspecies on 25 August 1965, Hubbs et al. (1974) described the fish as abundant in the spring complex. They greatly outnumbered another endemic, the Independence Valley speckled dace (Rhinichthys osculus lethoporus). A second collection of the tui chub was made on 3 April 1966 by S. H. Berwick and others. Since 1966, no collections of the Independence Valley tui chub are known. Recent surveys of the Warm Springs system conducted by Vinyard (1984) yielded a few speckled dace but no tui chub.

Between 1960 and 1966, largemouth bass (Micropterus salmoides) and bluegills (Lepomis macrochirus) were introduced into the Warm Springs system and the largemouth bass is now abundant (Vinyard 1984). Hubbs et al. (1974) reported the introduced bullfrog (Rana catesbeiana), common carp (Cyprinus carpio), and largemouth bass in the springs in 1965 and expressed concern for survival of the native fishes. Vinyard (1984) speculated that the introduced centrarchids were responsible for elimination of the tui chub. This appears to be a logical hypothesis, as G. $b$. isolata preferred midwater habitats that were easily invaded by largemouth 
bass, whereas the speckled dace may have largely escaped extirpation by finding refuge in shallow water with dense aquatic vegetation.

Extinction of the Independence Valley tui chub probably occurred during the late 1960 s or early 1970 s. Surveys of other springs in the valley for fishes have been unsuccessful (Vinyard 1984).

\section{Thicktail Chub Gila crassicauda \\ Baird and Girard}

At one time the thicktail chub, which attained lengths of $250 \mathrm{~mm}$, was one of the most common fishes in California's Central Valley and at the turn of the century was sold in markets in San Francisco. Examination of fish remains from historic Indian middens revealed the abundance of the chub. In one midden approximately $1 \mathrm{~km}$ west of the Sacramento River in Colusa County, thicktail chub was the most abundant species, contributing $41 \%$ of the 1,497 fish recovered (Schulz 1979). Museum records for the species during the late 1800 s and early 1900 s indicated a broad distribution throughout lower-elevation streams and rivers of the Central Valley, tributary streams of San Francisco Bay, central California coastal rivers, and Clear Lake (Rutter 1908; Miller 1963; Mills and Mamika 1980). In periods of heavy runoff, the species also inhabited fresh surface waters of San Francisco Bay (Ayres 1862). Preferred habitats consisted of rivers, marshes, sloughs, lakes, and slow-flowing reaches of rivers.

Primary causes of the decline of thicktail chub can be traced to conversion of much of the Central Valley to intensive agricultural production. Many of the sloughs and marshes were drained during the late 1800 s, and the remaining streams and rivers were largely dredged or channelized for navigation or flood control. Of the $34 \mathrm{mu}-$ seum lots of thicktail chub with collection dates, only $11(32 \%)$ were collected after 1900 . Habitat loss, combined with competition and predation pressures from a myriad of introduced nonnative fishes, probably combined to cause extinction of the thicktail chub. It was last collected from Clear Lake in 1938 and from the Sacramento River in 1950. The last known collection of the species was made from Steamboat Slough along the San Joaquin River,
Solano County, on 16 April 1957. Repeated efforts to find the species since that time have failed.

\section{Pahranagat Spinedace Lepidomeda altivelis Miller and Hubbs}

The Pahranagat spinedace was known from only two localities, the outflow of Ash Springs and Upper Pahranagat Lake, in Pahranagat Valley, Nevada. Miller and Hubbs (1960) reported collecting the spinedace in abundance at the two sites during 1938. It was not present in Crystal or Hiko springs or Ash Springs proper, indicating an avoidance of constant, warm water.

Extinction of the Pahranagat spinedace is most likely attributable to competition or predation by introduced species. In 1938, only a few common carp were collected with the spinedace from the outflow of Ash Springs, whereas this exotic was plentiful in Upper Pahranagat Lake. Common carp and another introduced species, the mosquitofish (Gambusia affinis), were abundant during a 1959 survey that yielded no Pahranagat spinedace (Miller and Hubbs 1960). The introduction of bullfrogs also may have contributed to the decline of the native fish by predation. The 1938 collection of Pahranagat spinedace is the last known, as numerous attempts to collect the species by Miller and Hubbs, and J. E. Deacon from the University of Nevada at Las Vegas, have failed.

\section{Ameca Shiner \\ Notropis amecae Chernoff and Miller}

The Ameca shiner was described from upper parts of the Rio Ameca drainage in Jalisco, Mexico (Chernoff and Miller 1986). The Río Teuchitlán, from which the type specimens were collected, lies about $75 \mathrm{~km}$ west of Guadalajara. Its waters are heavily utilized for drinking, irrigation, and other domestic uses and have been heavily polluted by humans and livestock.

The species was not common during the early 1900 s, as only 46 of 2,875 fishes collected from the upper Río Ameca basin between 1939 and 1969 were Notropis amecae. The last known capture of the Ameca shiner was on 21 April 1969. Intensive collecting in the drainage during the past 20 years has uncovered no shiners. Many habitats formerly occupied by native fishes are now populated by introduced fishes such as shortfin molly (Poecilia mexicana), platyfish (Xiphophorus), and tilapia (Tilapia). Thus, we fear that this Río Ameca endemic is extinct.

\section{Durango Shiner Notropis aulidion Chernoff and Miller}

The Durango shiner was native to the Rio Tunal, which forms the headwaters of the Río Mezquital, a Pacificslope river rising near Durango City, Durango, Mexico (Chernoff and Miller 1986). It was taken there only in 1951 and 1961. All specimens of this species were collected in a long, narrow reservoir on the Río Tunal at an elevation of $1,865 \mathrm{~m}$. Like its closest relatives, all of which occur south of Durango, this species evidently preferred quiet water. Collections farther upstream in the Rio Tunal (where the current is notable) failed to yield any specimens.

Since the mid-1960s, Durango City has grown considerably, with the result that streamflows have become reduced and domestic and industrial pollution have adversely affected surface waters. In addition, introduced species have seriously impacted native fishes by competition and predation. We believe that only 6 of the original 11 species known from the drainage still occur there. None of these six is a cyprinid. Introduced largemouth bass, in particular, have seriously affected the native biota. Attempts to locate the Durango shiner as recently as 1985 have failed, and we therefore doubt that the species survives.

\section{Phantom Shiner Notropis orca Woolman}

The phantom shiner, formerly confused with the bluntnose shiner, Notropis simus (Cope), has recently been recognized as a valid species. It was endemic to the Rio Grande from the mouth of the river at Boca Chica Beach, Texas, to central New Mexico, including the mouth of the Pecos River (Chernoff et al. 1982). Little is known about the biology of this species, as it has been collected only once in the past 38 years-a single adult taken in 1975 from the Mexican side of the lower Rio 
Grande.

Habitat alteration of the Rio Grande has been extensive as a result of water diversions, dams and their impoundments, chemical pollution and an increase in salinity that is correlated with irrigation projects. These factors, along with an abundance of introduced fishes, brought about a significant decline in abundance of both the phantom and bluntnose shiners, especially after 1940. Historically, the Rio Grande was characterized by floods and droughts, thus providing an unstable flow regime. The limited fish fauna may well have been adapted to these long-term unstable conditions. Introduced fishes, which often are greatly diminished during floods and droughts, flourished in the more stable flows.

Notropis simus and $N$, orca are known to have hybridized in the upper Rio Grande at Juarez, Mexico, as long ago as 1891 (Chernoff et al. 1982). By 1939, some individuals of $N$. simus taken in the river north of the Valencia (New Mexico) County line exhibited introgressive hybridization. The precise cause of hybridization is unknown, but likely was brought on by the reduction in number of spawning sites and/or rarity of one or both species. What role hybridization played in the decline of these species is unknown because we know so little about their biology.

\section{Rio Grande Bluntnose Shiner Notropis simus simus Cope Figure 4}

The bluntnose shiner was recently recognized as comprising two subspe- cies, N. s. simus from the upper Rio Grande between the Chama River and El Paso, Texas; and N. s. pecosensis from the Pecos River in New Mexico (Chernoff et al. 1982). Adult Rio Grande bluntnose shiners inhabited the swift, relatively deep, main river channel, but were occasionally taken from irrigation ditches or shallow riffles.

The last known Rio Grande bluntnose shiner was caught in the Rio Grande north of Peña Blanca, Sandoval County, New Mexico, on 28 July 1964 by R. D. Suttkus and class. As discussed above for the phantom shiner, a number of factors may have contributed to the extinction of the Rio Grande bluntnose shiner, including modifications of the river by dams and their impoundments, irrigation practices, and channelization. Loss of spawning sites by desiccation, perhaps in conjunction with competition from introduced species, may have been especially critical.

\section{Clear Lake Splittail Pogonichthys ciscoides Hopkirk}

Pogonichthys ciscoides was restricted to Clear Lake and its tributary streams in Lake County, California. This lacustrine cyprinid once formed large schools in Clear Lake, especially in the littoral zones. During April and May, the splittail ascended streams tributary to the lake to spawn (Moyle 1976). Hopkirk (1973) reported the species from several localities in Clear Lake during the early and mid-1960s, and a single specimen that apparently was washed downstream into Cache Creek, $0.6 \mathrm{~km}$ upstream from State
Highway 16 (1965).

The decline of the once abundant splittail parallels the drastic change in Clear Lake itself. Prior to the 1880s, the lake was a cool, clear habitat with a fishery dominated by rainbow trout and Sacramento perch (Archoplites interruptus) (Murphy 1951); by the early 1940 s, it had been transformed into a warm, turbid lake dominated by centrarchids, common carp, and other introduced fishes. Goldman and Wetzel (1963) documented the "extreme eutrophication" of Clear Lake by the late 1950s and attributed the change to rapid and poorly planned development of the watershed for agriculture, which washed sediment, fertilizers, and sewage into the lake. The Clear Lake splittail was abundant until 1942 or 1943 , but during three summers of intensive seining from 1946 to 1950, Murphy (1951) collected only a few juveniles. Murphy (1951) concluded that the low rainfallyears of the early 1940 s, coupled with diversion of tributary streams for agriculture, eliminated most of the habitat for the remaining splittails. The demise of the species may have been hastened by the application of large quantities of chlorinated hydrocarbon pesticides used to control swarms of Clear Lake gnats (Chaoborus astictopus). During the 1940s and 1950s, increasing use of DDD (dichloro-diphenyldichloroethane) resulted in the appearance of this toxin in fishes and piscivorous birds (Hunt and Bischoff 1960) and massive die-offs of western grebes (Aechmophorus occidentalis). Also, the abundance of introduced littoral fishes, such as bluegills and inland

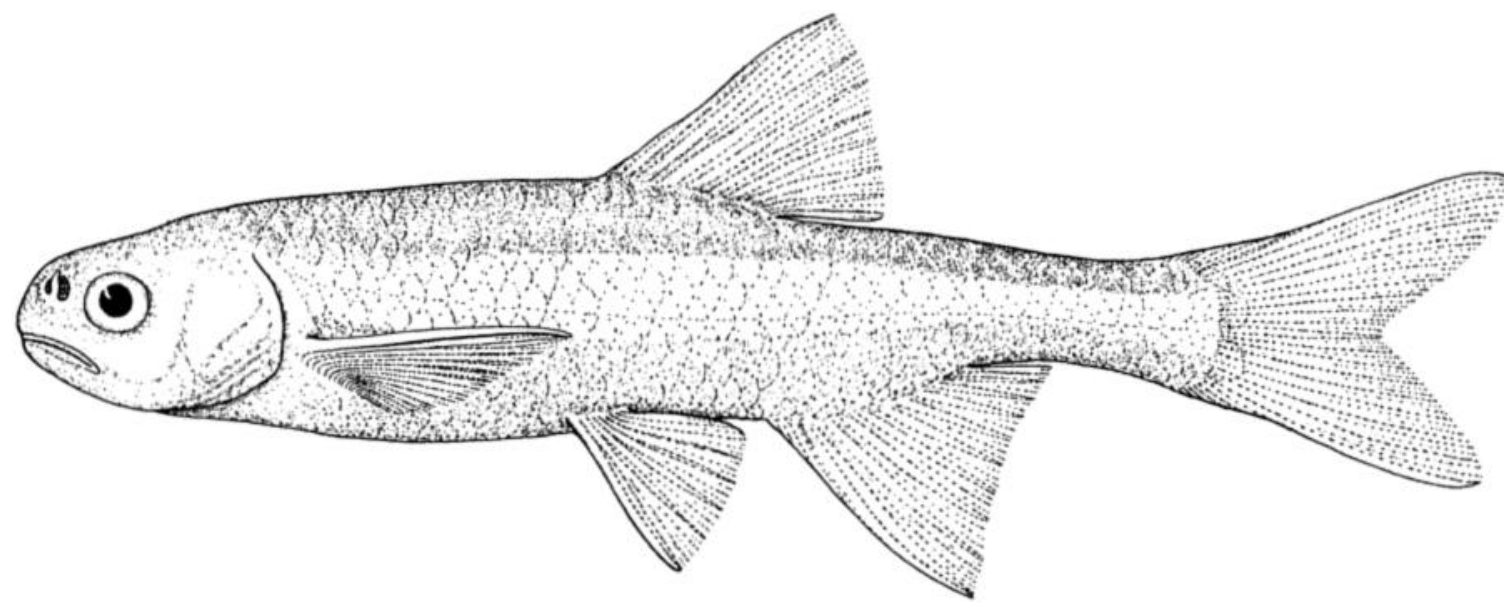

Figure 4. Rio Grande bluntnose shiner, Notropis s. simus. A specimen $65.2 \mathrm{~mm}$ SL, collected from Rio Grande $7 \mathrm{~km}$ north of Pena Blanca, Sandoval County, New Mexico. Drawing by Sara V. Fink. 
silverside (Menidia beryllina) probably was detrimental. The last specimen of Clear Lake splittail was taken from Clear Lake in 1970. Recent collection efforts have failed and the species is presumed to be extinct (Moyle 1976).

\section{Banff Longnose Dace Rhinichthys cataractae smithi Nichols}

The Banff longnose dace was endemic to the marsh created by Cave and Basin Hotsprings $1.7 \mathrm{~km}$ southwest of Banff, Alberta, Canada. Based on collection records during the late $1800 \mathrm{~s}$ and early 1900s, the Banff longnose dace was quite abundant in its restricted habitat (Lanteigne 1988). After the early 1900s, surveys revealed few specimens. In May 1971, 16 individuals were collected at the inflows, and 7 more from the same site in May 1981 (Lanteigne 1988). A September 1981 trip yielded only two specimens from a pool at the outlet of the marsh into the Bow River, but others were sighted in the same locality. Decreasing population size by 1981 indicated that the Banff longnose dace was endangered at that time, and more recent unsuccessful collection efforts indicate the subspecies to be extinct (Lanteigne 1988).

Initial decline of the Banff longnose dace can be attributed to introductions of numerous exotic and non-native fishes, including mosquitofish, which were stocked as early as 1924 (McAllister et al. 1985), and various tropical fishes such as sailfin mollies, guppies (Poecilia reticulata), convict cichlids (Cichlasoma nigrofasciatum), and green swordtails (Xiphophorus helleri), (Lanteigne 1988). Other factors contributing to the decline of the longnose dace are periodic cessation of flows related to use of the hotsprings as public baths, and the periodic spillage of sewage from the public facilities. Once the Banff longnose dace declined in numbers, it was susceptible to introgressive hybridization with the eastern subspecies of longnose dace (R. C. cataractae), which apparently caused its final extinction (Renaud and McAllister 1988).

\section{Las Vegas Dace}

Rhinichthys deaconi Miller

Between 1891 and 1940, several collections of a small minnow were made

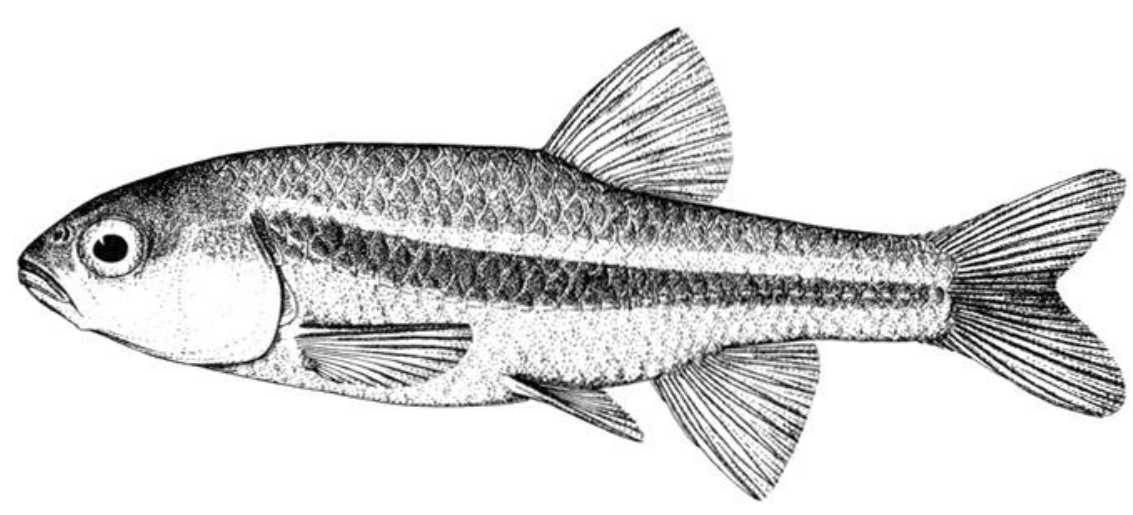

Figure 5. Stumptooth minnow, Stypodon signifer. The syntype, $40.0 \mathrm{~mm} \mathrm{SL}$, collected from a spring near Parras, Coahuila. Drawing by Sara V. Fink.

from Las Vegas Creek, near Las Vegas, Nevada. This dace was described by Miller (1984) and distinguished from its closest relative, the speckled dace (R. osculus).

In May 1844, John Fremont described Las Vegas Creek as "a delightful bathing place." In 1891, Vernon Bailey mentioned the numerous little fish in the springs and stream. Cottonwoods and willows grew along the banks. In high water, flow from Las Vegas Creek reached the Colorado River, some 40 $\mathrm{km}$ distant, but by 1947, flow down the creek had already been reduced by development of the Las Vegas community. Nothing is left of the spring and creek complex today, except a hole in the ground with stagnant water at the bottom. At one time, this creek and marsh also supported the endemic Vegas Valley leopard frog (Rana fisheri), which is also extinct. Both species were extirpated as the system was converted for agricultural and urban development.

The last known collection of the Las Vegas dace was made on 30 July 1940 , at Lorenzi Ranch in Las Vegas. The species probably survived in one of the springs and its outflow until about 1955, when there was a marked increase in the amount of water withdrawn from the artesian basin beneath Las Vegas. No fish were found 10 years later when the area was searched by J. E. Deacon and colleagues from the University of Nevada, Las Vegas.

\section{Grass Valley Speckled Dace Rhinichthys osculus reliquus Hubbs and Miller}

The Grass Valley speckled dace is known only from a single collection made by C. L. Hubbs and R. R. Miller on 9 August 1938. The collection locality was given by Hubbs and Miller (1972) as a "spring-fed creek in a grassy meadow in the partly enclosed southwestern arm of Grass Valley, $13 \mathrm{~km}$ east of Mt. Callaghan, in the course of Callaghan (Woodward) Creek, . . . in eastern Lander County, Nevada."

The speckled dace was common when collected in 1938. The single series consisted of 474 specimens. At that time, one trout was seen in the stream. A second collecting trip by Hubbs and Miller in 1969 produced only rainbow trout and brook trout from the stream (Hubbs et al. 1974). Ira La Rivers (University of Nevada, Reno, personal communication, to Hubbs) also reported finding no speckled dace, but only a stream "full of trout" during his visit to Grass Valley in about 1959. Efforts to collect this speckled dace from Grass Valley during the 1970 s also failed and the fish appears to be extinct. The introduction of trout probably is the primary cause of extinction, but use of the water for agriculture may have contributed to the loss.

\section{Stumptooth Minnow Stypodon signifer Garman Figure 5}

This species represents a monotypic genus known only from six specimens-two collected in 1880 and four in 1903. All specimens came from a spring or spring complex near Parras, in southern Coahuila, Mexico. The species was named for its large, molariform pharyngeal teeth, which evidently were specialized for feeding on the abundant mollusks. 
A 2-day search of Parras Valley in 1953, by C. L. and L. C. Hubbs, revealed Gila as the only surviving native fish. This was confirmed by ContrerasBalderas (1969). Habitat modification and loss of springs, and/or water pollution and irrigation practices that carried water onto cultivated fields were all important causal factors in the decline. The snails that were the food of the stumptooth minnow may have been particularly sensitive to changes in water level and deteriorating water quality.

\section{June Sucker}

\section{Chasmistes liorus liorus Jordan}

The June sucker (Chasmistes liorus), Utah sucker (Catostomus ardens), and their hybrids historically occurred in such great abundance in Utah Lake that it was referred to as the "greatest sucker pond in the universe" (Jordan and Gilbert 1881). June suckers were restricted to Utah Lake, except during late spring (typically in June--hence the common name), when they ascended tributary streams for spawning. Commercial fishermen harvested the suckers during their spawning runs in the Provo and Spanish Forks rivers as well as in Utah Lake during winter.

Diversion of inflowing streams for irrigation decreased the lake's commercial fisheries for the sucker and native cutthroat trout as early as 1860 (Winter, personal communication, in Heckmann et al. 1981). Diversion dams on tributary rivers also blocked spawning runs and caused hybridization between the two sucker species as they were concentrated in the dam's tailwaters. Introductions of 25 exotic and non-native fishes, also contributed to decline of the native fishes. Eleven of these were established in Utah Lake or its tributaries prior to 1930 (Heckmann et al. 1981).

The final collapse of the June sucker appeared to result from the severe drought of the mid-1930s. Tanner (1936) succinctly described the final demise of genetically pure June suckers as follows: "At this writing Jan. 1936, practically all the suckers as well as other fish in Utah Lake have been killed by the severe drought of the past four years. . . During the winter of 193435 the water was so shallow that hundreds of tons of suckers and carp were killed due to freezing and crowding in the few deep holes. . . In the spring of 1935 there were no suckers to run up Provo River, something that has never happened before in the history of Utah Lake."

A Chasmistes now exists in Utah Lake, but it differs significantly from type specimens of $C$. liorus. The true-breeding population of Chasmistes from Utah Lake was described as a new subspecies, C. liorus mictus, that resulted from hybridization between the June and Utah suckers (Miller and Smith 1981). Unlike previous hybrids in the lake, this subspecies of June sucker comprised a large breeding population with consistent, distinguishable characters. The original form of June sucker, C. $l$. liorus, is extinct (Miller and Smith 1981).

\section{Snake River Sucker Chasmistes muriei Miller and Smith Figure 6}

The Snake River sucker is known only from a single specimen collected by Dr. Olaus J. Murie from the Snake
River below Jackson Lake Dam, Wyoming, on 13 October 1927 (Miller and Smith 1981). The species is presumed to have occupied Jackson Lake and perhaps other lakes on the upperSnake River. Like other members of the genus Chasmistes, the Snake River sucker was a lacustrine species with numerous dendritic gill rakers for feeding on plankton.

Chasmistes muriei may have been extinct in genetically pure form when the only specimen was collected in 1927. By this time, introgression of the Utah sucker with the Snake River sucker was evident. A rock-filled dam was constructed on the outflow of Jackson Lake in 1905-1906. After this dam was washed out in 1910, construction began the next year on a concrete dam that would eventually almost double the surface area of Jackson Lake (J. Daugherty, National Park Service, personal communication). Hybridization with the Utah sucker probably occurred because such dams on the upper Snake River blocked spawning migrations and forced remaining suckers to spawn in the dams' tailwaters. Had it not been for the diligence of wilderness advocate Dr. Murie, who collected the only specimen, the passage of this species into extinction would have gone unnoticed.

\section{Harelip Sucker Lagochila lacera Jordan and Brayton Figure 7}

During the late $1800 \mathrm{~s}$, the harelip sucker was widespread in the eastern United States, where it occurred in at least eight states. Museum records exist for the Chickamanga River (GA), Elk River (TN), Scioto River and Maumee

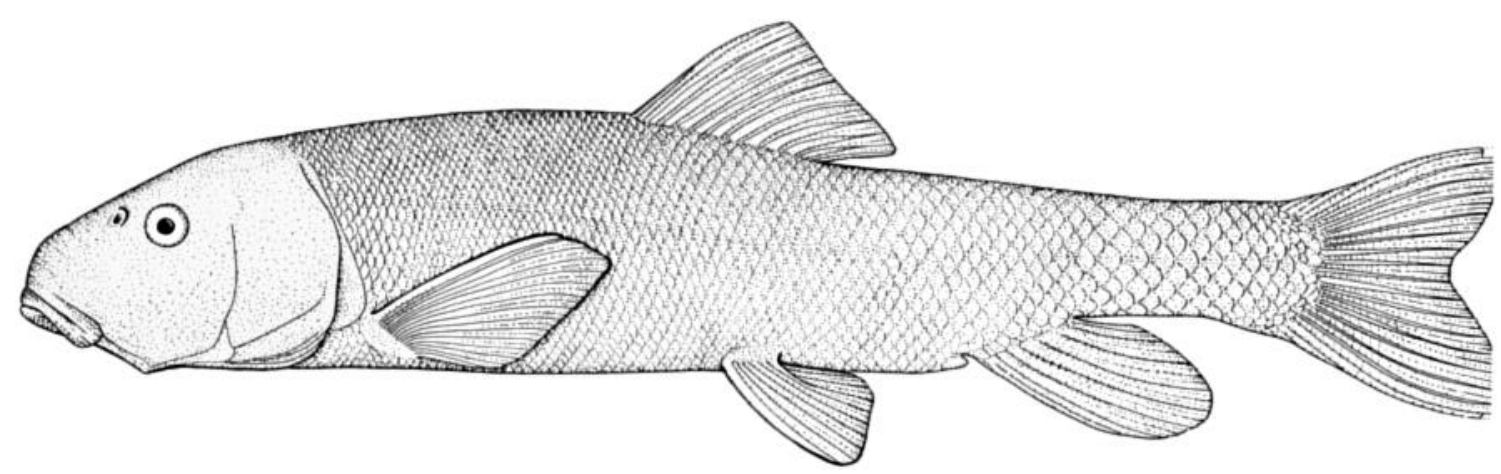

Figure 6. Snake River sucker, Chasmistes muriei. An adult female, $371 \mathrm{~mm}$ SL, collected from the Snake River below Jackson Lake Dam, Teton County, Wyoming, 13 October 1927. Drawing by Sara V. Fink. 


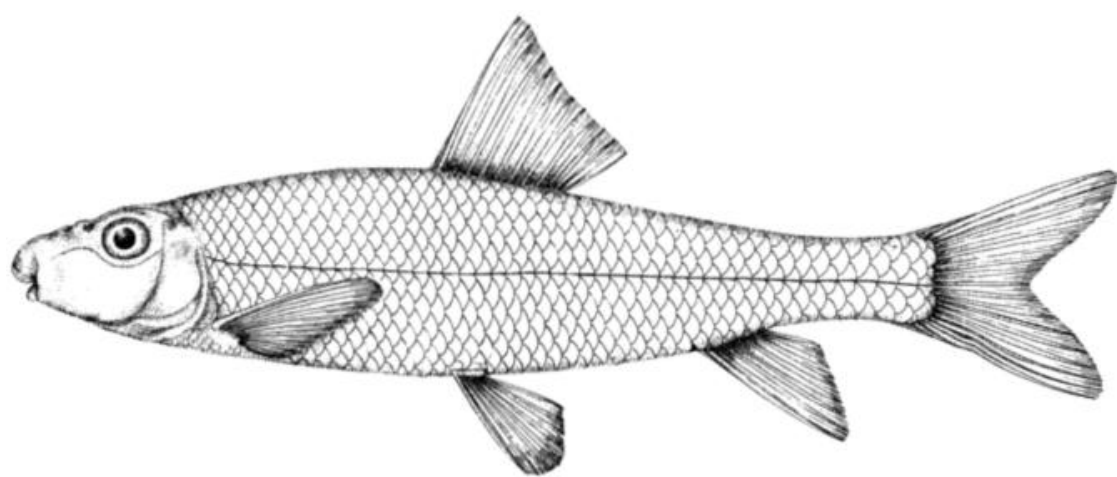

Figure 7. Harelip sucker, Lagochila lacera. Specimen collected at Fairview, Williamson County, Tennessee, sometime before May 1880. Drawing by H. L. Todd.

River $(\mathrm{OH})$, Tennessee River drainage (Al, TN, VA), Cumberland River drainage (KY, TN), and Tippecanoe River (IN) (Jordan 1882, 1890; Evermann and Jenkins 1889; Woolman 1892; Kirsch 1896). Although the distribution of the harelip sucker was widespread, its habitat appears to have been restricted to deep pools between shoal areas with clear water over a bedrock or rocky bottom in moderate to large streams. Most collectors reported the species as "abundant," "common," or "not rare."

Some life history data are available from studies of catostomid brain and lips (Miller and Evans 1965) that noted the large optic brain lobes of the harelip sucker and its highly modified lips with few taste buds. These characteristics indicate visual location of foods. Examination of stomach contents of nine harelip suckers revealed that about $90 \%$ of the food items were mollusks (R. E. Jenkins, Roanoke College, personal communication).

The decline and ultimate extinction of the species may be attributable to increased turbidity and siltation of its clearwater pool habitats as a result of agricultural practices. Siltation and pollution could have greatly reduced mollusk populations and impaired the ability of the sucker to visually locate foods. The species was last collected in 1893 , but it probably did not become extinct until the early 1900 s based on reports of the harelip sucker as "common" in the 1880 s and 1890 s.

\section{Parras Pupfish Cyprinodon latifasciatus Garman}

The Parras pupfish is known only from two collections made in 1880 and
1903, from a spring or spring complex near Parras in southern Coahuila, Mexico. The species was collected at the same time as the stumptooth minnow, now also extinct. Until the early 1930 s, Parras Valley contained magnificent spring systems. Subsequent development of extensive wine factories, a flour mill, rubber mill, and textile factory (Imlay 1936) seriously reduced and greatly modified available surface water. By 1953, when an extensive attempt was made to collect or observe this species again, no trace of it was found. The extinction of the Parras pupfish, like that of the stumptooth minnow, was probably caused primarily by the failure of spring flows. Industrial and domestic pollution also likely contributed to the decline.

\section{Tecopa Pupfish \\ Cyprinodon nevadensis calidae Miller}

The Tecopa pupfish was known from outflows of two hot springs near $\mathrm{Te}$ copa, Inyo County, California (Miller 1948). The species was fairly common in water of $36.5^{\circ} \mathrm{C}$ and abundant in water of 32 to $36^{\circ} \mathrm{C}$.

Modification of North and South Tecopa Hot Springs for use as bathhouses resulted in the decline and eventual extinction of the Tecopa pupfish. Pools were enlarged and outflow creeks were ditched and diverted. Channelization of the outflow allowed the Amargosa pupfish (Cyprinodon $n$. amargosae) from the nearby Amargosa River to gain access to habitat of the Tecopa pupfish. This resulted in hybridization and continued loss of the calidae genome by introgression. The introduction of mosquitofish also con- tributed to the decline.

Extinction of the Tecopa pupfish occurred in late 1970 or soon thereafter. Six pupfish collected by D. V. Hemphill on 28 March 1954 from "Tecopa Hot Springs Well" represent this subspecies. A more recent collection from the same place by R. Papp and others on 2February 1970 comprises nine pupfish that are clearly referable to $C$. $n$. calidae, three that are probably referable to $C$. $n$. calidae, and three that are introgressed with $C$. $n$. amargosae. This is the last known collection of the Tecopa pupfish. Surveys in 1972 by R. R. Miller and in 1977 by D. A. Selby confirmed extinction of the subspecies. This pupfish was the first creature to be declared officially extinct under provisions of the Endangered Species Act of 1973.

\section{Monkey Spring Pupfish Cyprinodon sp.}

This undescribed species of pupfish was restricted to Monkey Spring, a tributary to the Santa Cruz River system in Santa Cruz County, Arizona (Minckley 1973). The species occurred in abundance in the spring and an extensive ciénega formed by its outflow.

Attempts to impound and deepen the ciénega apparently "broke the seal," which resulted in draining of the marsh (Minckley 1973). The pupfish remained abundant in the spring until largemouth bass were introduced in 1968 and 1969. Minckley (1973) reported that a few pupfish escaped predation by largemouth bass until late 1969, when the species was extirpated in its natural habitat. Introduction of the bass also extirpated the local stock of Gila chub (Gila intermedia), which "was markedly different from other stocks" of the species (Minckley 1973). Captive stocks of Monkey Spring pupfish failed in 1971, thus eliminating any hope for survival of Arizona's only single-spring endemic fish species.

\section{Raycraft Ranch Poolfish Empetrichthys latos concavus Miller Figure 8}

Miller (1948) described Empetrichthys latos from Pahrump Valley, Nevada, and recognized three subspecies from springs located along the east side of the valley. The Raycraft Ranch poolfish occurred only in one spring on Raycraft 


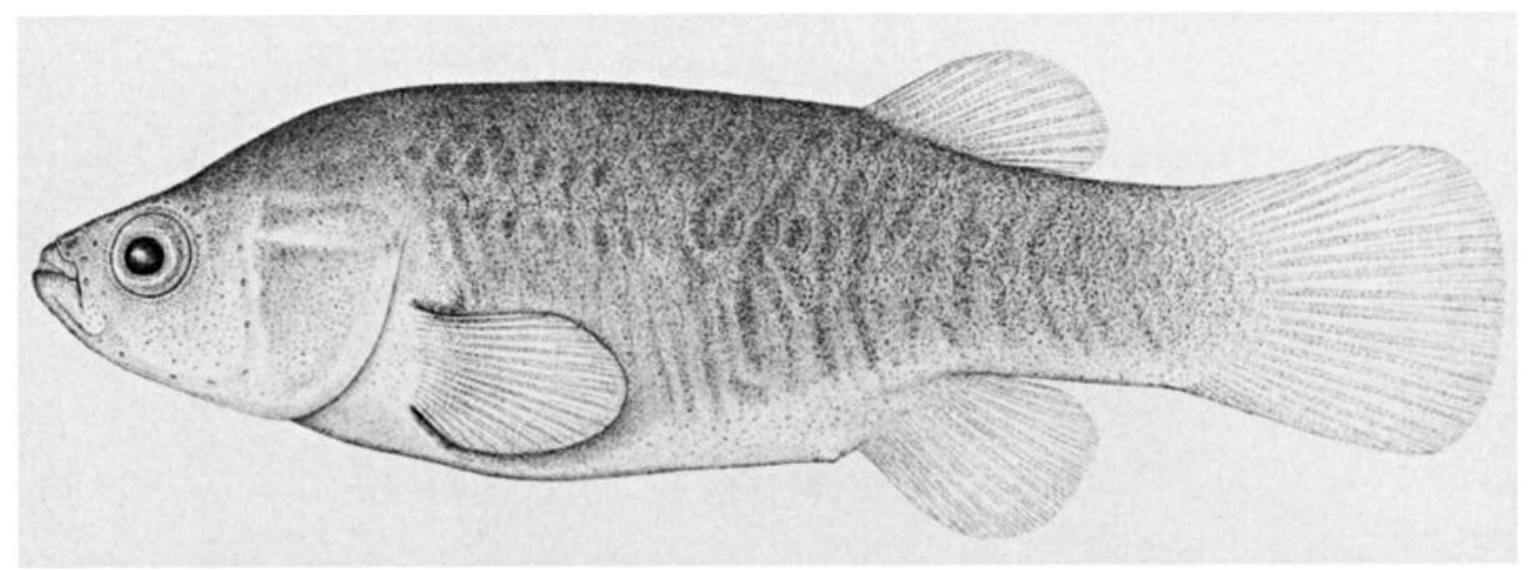

Figure 8. Raycraft Ranch poolfish, Empetrichthys latos concavus. The holotype, a $39.0 \mathrm{~mm}$ SL adult female, collected from Raycraft Ranch, Nye County, Nevada. Drawing by Sara V. Fink.

Ranch, about $0.8 \mathrm{~km}$ north of Pahrump Ranch.

When collecting the type series in 1942, Miller (1948) noted that the subspecies "was not common" and suggested that reduced numbers were caused by introduced carp. Sokol (1954) reported the last known collection of the Raycraft Ranch poolfish in late September 1953. Twelve specimens were collected at that time and Sokol (1954) commented on the presence of introduced carp and bullfrogs. Miller (1961) reported correspondence from Ira La Rivers who surveyed Pahrump Valley in about 1958 and found that only one spring formerly inhabited by poolfish in the valley was relatively undisturbed. It appears that the Raycraft Ranch poolfish became extinct in about 1960. The spring was subsequently filled to control mosquitoes.

\section{Pahrump Ranch Poolfish Empetrichthys latos pahrump Miller}

The Pahrump Ranch poolfish was known only from two springs located about $180 \mathrm{~m}$ east of the ranch house on Pahrump Ranch, Nye County, Nevada (Miller 1948). When Robert $R$. and Frances $H$. Miller collected the type series in October 1942, they noted that the northernmost of the two springs had been greatly altered by dredging and no poolfish were observed there. The other spring still supported a poolfish population in a marsh formed by the spring outflow.

Sokol (1954) visited the springs in September 1953, but was unable to find any poolfish. Ira La Rivers reported to Miller (1961) that all subspecies were extant during his surveys of about 1958 , but that carp and bullfrogs were abundant and that the spring sources were periodically pumped dry. Extinction of the Pahrump Ranch poolfish probably occurred in 1958, when one of the springs failed because of excessive pumping.

\section{Ash Meadows Poolfish Empetrichthys merriami Gilbert}

The genus Empetrichthys and the Ash Meadows poolfish ( $E$. merriami) were described by Gilbert (1893) on the basis of specimens collected from Ash Meadows, Nevada, on 3-5 March 1891. It appears that the poolfish may have been rare even at the time it was discovered; only seven specimens were collected, whereas numerous specimens of speckled dace were taken. The Ash Meadows poolfish was next collected in 1930, when George S. Myers and Joseph $\mathrm{H}$. Wales obtained three specimens. Despite concerted efforts from 1936 to 1942, Ralph G. and Robert R. Miller collected only 22 specimens from Big, Jack Rabbit, Point of Rocks, Forest, and Rogers springs (Miller 1948). The last known individual was collected from Big Spring (=Deep Spring of Miller 1948) on 7 September 1948 by W. Hildemann and John A. Kopec. Sokol (1954) attempted unsuccessfully to collect Ash Meadows poolfish from Big Spring in 1953. Numerous efforts since then have failed.

Introductions of bullfrogs and crayfish (Procambarus clarkii) were first noticed in habitats of the Ash Meadows poolfish in 1937 (Miller 1948). Both introduced species undoubtedly preyed on the poolfish and may have been the primary causal factor in its extinction, which probably occurred in the early 1950s. Habitat alteration also may have been a contributing factor in some springs.

\section{Whiteline Topminnow Fundulus albolineatus Gilbert}

The whiteline topminnnow occurred only in Spring Creek at Huntsville, Alabama. The only known specimens are the original 20 type specimens collected on 27 May 1889 by P. H. Kirsch, plus 5 others taken on the same date. The species appeared to be restricted to Big Spring and its $0.3 \mathrm{~km}$ long outflow, Spring Creek.

Armstrong and Williams (1971) described unsuccessful efforts to collect the whiteline topminnow in 1966. Instead they found numerous common carp and goldfish (Carassius auratus) in a spring system modified by small dams, channelization, and surrounded by concrete walls. According to local residents, Big Spring historically was used as a water supply for the city of Huntsville and was pumped dry on several occasions. More than 25 springs and their outflows in the vicinity of Huntsville have been sampled during the past 7 years but the species has not been found (D. A. Etnier, University of Tennessee, personal communication). It appears that the whiteline topminnow is extinct.

\section{Opal Allotoca Allotoca maculata Smith and Miller}

The opal allotoca was described from collections made on 22 February 1970 
at Laguna de Santa Magdalena, about $82 \mathrm{~km}$ west of Guadalajara in Jalisco, Mexico (Smith and Miller 1980). The species also is known from a reservoir near Etzatlán. Both waters are within the isolated Magdalena Basin. This small goodeid inhabited shallow lake margins and adjacent marshes.

Attempts by ichthyologists to collect this species in recent years have failed. Alfred Radda (Institüt für Virologie, University of Vienna, personal communication) tried three times and Bruce J. Turner once. The exact cause of its disappearance is not known but may be related to shrinkage of the restricted habitat from increasing use of groundwater in the basin by the expanding human population in Magdalena. No exotic species have been reported from the Laguna de Santa Magdalena area.

\section{Parras Characodon Characodon garmani Jordan and Evermann}

This goodeid, only recently recognized as a valid species (Smith and Miller 1986), is known only from a single specimen collected from Parras Valley in southern Coahuila, Mexico. The adult female was obtained by Edward Palmer, probably in the 1880s. Parras Valley supported a highly endemic fish fauna, which largely disappeared near the turn of the century (Williams et al. 1985). The extinction of the Parras characodon, like that of the stumptooth minnow and Parras pupfish, was probably caused by the physical alteration of spring habitats.

\section{Amistad Gambusia Gambusia amistadensis Peden}

The Amistad gambusia was endemic to Goodenough Spring and its outflow in Val Verde County, Texas (Peden 1973). When the first specimens of Amistad gambusia were collected on 11 April 1968, their habitat was already threatened by waters rising behind the newly constructed Amistad Dam on the Rio Grande. By 3 August, rising waters covered the spring, but Alex E. Peden collected 30 to 40 live Amistad gambusia from flooded prickly pear and mesquite. By April 1969, the spring was covered to a depth of $23.2 \mathrm{~m}$.

The stock was successfully propagated at The University of Texas at
Austin. On 30 November 1974, about 35 fish from this stock were transferred to Dexter National Fish Hatchery in New Mexico for propagation. Unfortunately, examination of both stocks revealed that they were contaminated with mosquitofish, which resulted in extinction of the Amistad gambusia (Hubbs and Jensen 1984). The university stock may have been contaminated before the fish were transferred to Dexter. mental plant, elephant ears (Colocasia asculenta), restricted suitable habitat in the river to the areas sprayed with herbicides. All of these factors contributed to the decline of the species. As numbers of San Marcos gambusia were reduced, hybrids with Gambusia affinis became more predominant. Genetically pure $G$. georgei have not been collected since 1983 and the species is presumed to be extinct (Johnson and Hubbs 1989).

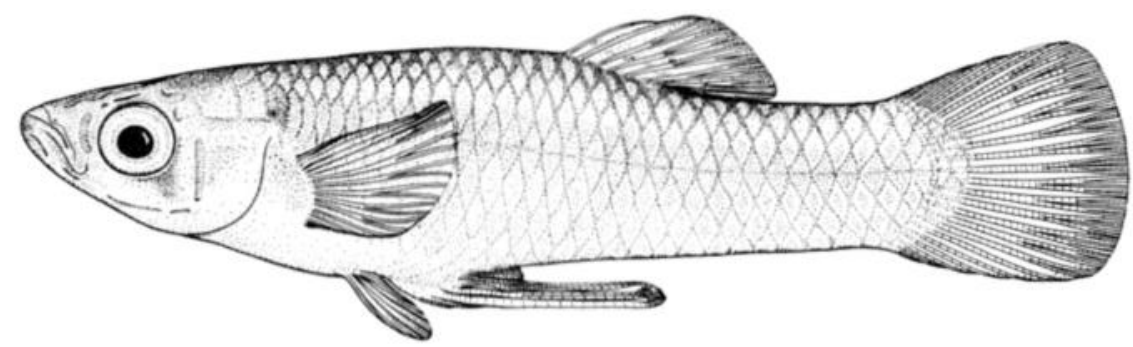

Figure 9. San Marcos gambusia, Gambusia georgei. A male (holotype), $29.3 \mathrm{~mm}$ SL, collected from the San Marcos River at the I-35 bridge, Hays County, Texas, on 7 March 1968. Drawing by Sara V. Fink.

\section{San Marcos Gambusia \\ Gambusia georgei \\ Hubbs and Peden Figure 9}

Type specimens of the San Marcos gambusia were collected by Clark Hubbs and Michael M. Stevenson on 7 March 1968 from the San Marcos River in Hays County, Texas (Hubbs and Peden 1969). They occurred only in thermally constant, shallow areas of the river characterized by mud bottoms and a lack of vegetation. Hubbs and Peden (1969) remarked on the fragile nature of its existence because of its narrow habitat requirements and segregation from two other native species of Gambusia in the San Marcos River.

Springs on the San Marcos River have been altered by increased pumping of groundwater for urbanization. Pollution, including the use of herbicides along the river, appears to have adversely affected the habitat of the San Marcos gambusia. In addition, the following introduced fishes have been recorded in habitats typically occupied by G. georgei: Mexican tetra (Astyanax mexicanus), sailfin molly, Amazon molly (Poecilia formosa), smallmouth bass (Micropterus dolomieui), redear sunfish (Lepomis microlophus), and others (Edwards et al. 1984). Finally, and perhaps most critically, the spread of an orna-

\section{Blue Pike \\ Stizostedion vitreum glaucum Hubbs}

The blue pike was primarily known from Lake Erie, but also occurred in Lake Ontario, the lower Niagara River, and rarely in Lake Huron (Deason 1936; S. H. Smith, Fish and Wildlife Service, Ann Arbor, MI, personal communication). It was an important species in the commercial fishery of Lakes Erie and Ontario, especially in Lake Erie where the annual catch until the mid1950 s was between 5 and 10 million $\mathrm{kg}$ (Deason 1936). By 1950 the fishery was in a substantial decline and by 1959 the total catch was only $35,834 \mathrm{~kg}$. The last confirmed specimen was taken from Lake Erie in 1965, and no reliable reports of this fish exist past 1970.

The physical, chemical, and biological environments of Lakes Erie and Ontario deteriorated measurably from the 1940 s to the 1960 s. Enrichment of the lakes and depletion of dissolved oxygen created conditions unfavorable for pike eggs and young. Impacts from introduced fishes and overharvesting by selective commercial and sport fisheries also contributed to the decline during this period. Hybridization and introgression between the blue pike and walleye (S. v. vitreum) also were 


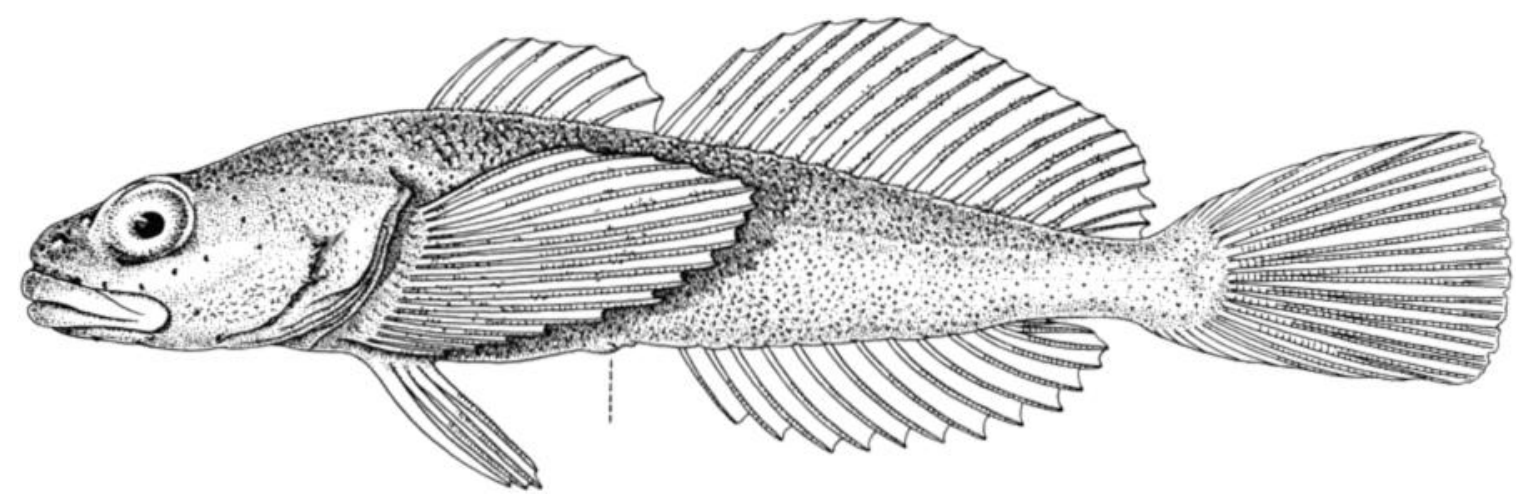

Figure 10. Utah Lake sculpin, Cottus echinatus. An adult female, $64.5 \mathrm{~mm} \mathrm{SL}$, collected from Utah Lake at the mouth of the Provo River, Utah County, Utah, during April 1928. Drawing by Suzanne Runyan.

involved in the demise of the blue pike (Regier et al. 1969). All of the above factors contributed to the extinction of the blue pike.

\section{Utah Lake Sculpin}

\section{Cottus echinatus Bailey and Bond} Figure 10

The original description of the Utah Lake sculpin was based on seven specimens collected from Utah Lake, Utah, between 1880 and 1928 (Bailey and Bond 1963). The species apparently was strictly lacustrine as it has never been taken outside the lake.

As described earlier for the June sucker, increased pollution and salinity by developing agriculture greatly diminished water quality in Utah Lake during the late 1800 s and early 1900 s. In addition, at least 11 non-native and exotic fishes became established in Utah Lake or its tributaries before 1930 (Heckmann et al. 1981). Extreme drought and low water conditions of the mid-1930s apparently extinguished the remaining Utah Lake sculpins. The last known specimen was collected by Vasco M. Tanner in April 1928.

\section{Summary}

During the past 100 years, activities of mankind have caused the extinction of 40 taxa of North American fishes: 27 species, and 13 subspecies (as well as 3 genera) have been lost (Table 1). The minnow family (Cyprinidae) has lost more members (16 taxa) than any other family of fishes. A large number of salmonids and cyprinodontids, seven taxa each, are also extinct. Regions that have lost a substantial proportion of their native fish fauna are the Great
Lakes (three species and two subspecies), Great Basin (one species and six subspecies), Parras Valley (three species including one monotypic genus), Valley of Mexico (one genus and three species), and Rio Grande (two species and two subspecies).

For most extinct fishes, more than a single factor was responsible for their decline and subsequent extirpation ( $\mathrm{Ta}$ ble 2). The most common cause of extinction was habitat loss, a contributing factor for at least $73 \%$ of the 40 taxa. The second most common causal factor was the effects of introduced species (cited for $68 \%$ of the 40 taxa). These factors were followed by chemical alteration or pollution (38\%), hybridization $(38 \%)$, and overharvesting (15\%).

Unfortunately, the rate of extinction of North American fishes is likely to increase. Of the 40 taxa treated here, 19 have disappeared since 1964 . Present laws and recovery activities appear inadequate to stem the increasing tide of endangered fishes (Williams et al. 1989). We are especially concerned for the fate of the Mexican ichthyofauna, where the fishes are poorly known, environmental protection laws are inadequate, and the human population is rising at a staggering rate.

\section{Acknowledgments}

We greatly appreciate the assistance of E. Diaz-Pardo, K. E. Hartel, S. L. Jewett, G. R. Smith, and T. N. Todd. Dean $A$. Hendrickson assisted in preparation of the resumen. Funding for illustrations by Sara V. Fink was kindly provided by Mrs. Virginia Ullman. Additional support was provided by a Faculty Assistance Fund grant to Rob- ert Miller and by a grant from the California-Nevada Chapter of AFS. The illustrations of the harelip sucker and silver trout are courtesy of the U.S. National Museum of Natural History and are deposited in the files of the Division of Fishes, Department of Vertebrate Zoology, Smithsonian Institution. The U.S. Fish and Wildlife Service provided publishing funds.)

\section{References}

Alvarez, J., and L. Navarro G. 1957. Los peces del Valle de México. Sec. de Marina. Dir. Pesca Indus. Conex., Méx. 1957:162.

Andreasen, J. K. 1975. Systematics and status of the family Catostomidae in southern Oregon. Doctoral dissertation. Oregon State Univ., Corvallis. $76 \mathrm{pp}$.

Armstrong, J. G., and J. D. Williams. 1971. Cave and spring fishes of the southern bend of the Tennesee River. J. Tenn. Acad. Sci. 46:107-115.

Ayres, W. O. 1862. Occurrence of freshwater fishes in San Francisco Bay. Proc. Calif. Acad. Nat. Sci. 2:163.

Bailey, R. M., and C. E. Bond. 1963. Four new species of freshwater sculpins, genus Cottus, from western North America. Occas. Pap. Mus. Zool. Univ. Mich. 634:1-27.

Bailey, R. M., and W. J. Richards. 1963. Status of Poecilichthys hopkinsi Fowler and Etheostoma trisella, new species, percid fishes from Alabama, Georgia, and South Carolina. Occas. Pap. Mus. Zool. Univ. Mich. 630:1-21.

Barbour, C. D., and R. R. Miller. 1978. A revision of the Mexican cyprinid fish genus Algansea. Misc. Publ. Mus. Zool. Univ. Mich. 155:1-72.

Behnke, R. J. 1979. Monograph of the native trouts of the genus Salmo of western North America. USDA Forest Service, Lakewood, CO. 163 pp. 
Table 1. Recently extinct fishes of North America. Location codes follow those given by Williams et al. (1989). Dates of extinction are approximate for most taxa (see text).

Common name, scientific name

Location

Whiteline topminnow, Fundulus albolineatus

Parras characodon, Characodon garmani

Yellowfin cutthroat trout, Oncorhynchus clarki macdonaldi

Harelip sucker, Lagochila lacera

Snake River sucker, Chasmistes muriei

Utah Lake sculpin, Cottus echinatus

Silver trout, Salvelinus agassizi

Stumptooth minnow, Stypodon signifer

Parras pupfish, Cyprinodon latifasciatus

June sucker, Chasmistes l. liorus

Alvord cutthroat trout, Oncorhynchus clarki ssp.

Pahranagat spinedace, Lepidomeda altivelis

Grass Valley speckled dace, Rhinichthys osculus reliquus

Miller Lake lamprey, Lampetra minima

Ash Meadows poolfish, Empetrichthys merriami

Deepwater cisco, Coregonus johannae

Las Vegas dace, Rhinichthys deaconi

Thicktail chub, Gila crassicauda

Pahrump Ranch poolfish, Empetrichthys latos pahrump

Maravillas red shiner, Cyprinella lutrensis blairi

Raycraft Ranch poolfish, Empetrichthys l. concavus

Rio Grande bluntnose shiner, Notropis simus simus

Durango shiner, $N$, aulidion

Lake Ontario kiyi, Coregonus kiyi orientalis

Blackfin cisco, C. nigripinnis

Mexican dace, Evarra bustamantei

Mexican dace, E. eigenmanni

Mexican dace, E. tlahuacensis

Independence Valley tui chub, Gila bicolor isolata

Ameca shiner, Notropis amecae

Clear Lake splittail, Pogonichthys ciscoides

Blue pike, Stizostedion vitreum glaucum

Tecopa pupfish, Cyprinodon nevadensis calidae

Monkey Spring pupfish, Cyprinodon sp.

Amistad gambusia, Gambusia amistadensis

Phantom shiner, Notropis orca

Longjaw cisco, Coregonus alpenae

Banff longnose dace, Rhinichthys cataractae smithi

San Marcos gambusia, Gambusia georgei

Opal allotoca, Allotoca maculata

$\begin{array}{cc}\text { AL } & 1900 \\ \text { COA } & 1900 \\ \text { CO } & 1910\end{array}$

AL, AR, IN, KY, $\quad 1910$

$\mathrm{GA}, \mathrm{OH}, \mathrm{TN}, \mathrm{VA}$

WY 1928

UT 1928

$\mathrm{NH} \quad 1930$

COA 1930

COA 1930

UT 1935

NV, OR 1940

NV 1940

NV 1950

OR 1953

NV 1953

IL, IN, MI, WI; ON 1955

NV 1955

CA 1957

NV 1958

TX 1960

NV 1960

NM, TX; CHI 1964

DGO 1965

NY; ON 1967

IL, IN, MI, WI; ON 1969

DFE $\quad 1970$

DFE $\quad 1970$

DFE $\quad 1970$

NV $\quad 1970$

JAL 1970

CA 1970

MI, NY, OH, PA; ON 1970

CA 1971

AZ 1971

TX 1973

NM, TX; CHI, TAM 1975

IL, IN, MI, NY, $\quad 1978$

$\mathrm{OH}, \mathrm{PA}, \mathrm{WI} ; \mathrm{ON}$

AB 1982

TX 1983

JAL 1984
1980. A systematic review of the genus Salvelinus. Pages $441-480$ in E. K. Balon, ed. Charrs salmonid fishes of the genus Salvelinus. W. Junk Publ., The Netherlands.

Bigelow, S. L. 1850 . Observations on some of the habits of Salmo fontinalis. Boston J. Nat. Hist. 6:49.

Bond, C. E., and T. T. Kan. 1973. Lampetra (Entosphenus) minima n. sp., a dwarfed parasitic lamprey from Oregon. Copeia 1973:568-574.

Campbell, R. R. 1985. Rare and endangered fishes and marine mammals of Canada: COSEWIC fish and marine mammals subcomittee status reports: II. Can. FieldNat. 99:404-408.

—. 1988. Rare and endangered fishes and marine mammals of Canada: $\mathrm{CO}$ SEWIC fish and marine mammal subcommittee status reports: IV. Can. Field-Nat. 102:81-86.

Chernoff, B., and R. R. Miller. 1986. Fishes of the Notropis calientis complex with a key to the southern shiners of Mexico. Copeia 1986:170-183.

Chernoff, B., R. R. Miller, and C. R. Gilbert. 1982. Notropis orca and Notropis simus, cyprinid fishes from the American Southwest, with description of a new subspe- cies. Occas. Pap. Mus. Zool. Univ. Mich. 698:1-49.

Contreras-Balderas, S. 1969. Perspectives de la ictiofauna en las zonas aridas del norte de México. Pages 293-304 in Mem. Simp. Intern, sobre el aumento de la próduccion de alimentos en zonas aridas. ICASALS Pub. 3.

_ـ 1978. Speciation aspects and manmade community composition changes in Chihuahuan desert fishes. Pages 405-431 in R. H. Wauer and D. H. Riskind, eds. Transactions of the symposium on the biological resources of the Chihuahuan Desert region. U.S. Natl. Park Serv. 
Table 2. Summary of factors responsible for decline and eventual loss of extinct fishes. A plus sign $(+)$ indicates that the factor at least contributed to the extinction; a minus sign $(-)$ indicates no known effect.

\begin{tabular}{|c|c|c|c|c|c|}
\hline Scientific name & $\begin{array}{l}\text { Physical habitat } \\
\text { alteration }\end{array}$ & $\begin{array}{l}\text { Introduced } \\
\text { species }\end{array}$ & $\begin{array}{l}\text { Chemical alteration } \\
\text { or pollution }\end{array}$ & Hybridization & Overharvesting \\
\hline Lampetra minima & - & - & + & - & - \\
\hline Coregonus alpenae & - & + & - & + & + \\
\hline C. johannae & - & + & - & + & + \\
\hline C. kiyi orientalis & - & + & + & - & + \\
\hline C. nigripinnis & - & + & - & + & + \\
\hline Oncorhynchus clarki macdonaldi & - & + & - & + & - \\
\hline O. clarki ssp. & - & + & - & + & - \\
\hline Salvelinus agassizi & - & + & - & + & + \\
\hline Cyprinella lutrensis blairi & - & + & - & - & - \\
\hline Evarra bustamantei & + & - & + & - & - \\
\hline E. eigenmanni & + & - & + & - & - \\
\hline E. Hlahuacensis & + & - & + & - & - \\
\hline Gila bicolor isolata & - & + & - & - & - \\
\hline G. crassicauda & + & + & - & - & - \\
\hline Lepidomeda altivelis & - & + & - & - & - \\
\hline Notropis amecae & + & + & + & - & - \\
\hline$N$. aulidion & + & + & + & - & - \\
\hline N. orca & + & + & - & + & - \\
\hline N. simus simus & + & + & - & + & - \\
\hline Pogonichthys ciscoides & + & + & + & - & - \\
\hline Rhinichthys cataractae smithi & + & + & + & + & - \\
\hline R. deaconi & + & - & - & - & - \\
\hline R. osculus reliquus & + & + & - & - & - \\
\hline Stypodon signifer & + & - & + & - & - \\
\hline Chasmistes l. liorus & + & + & - & + & - \\
\hline C. muriei & + & - & - & + & - \\
\hline Lagochila lacera & + & - & + & - & - \\
\hline Cyprinodon latifasciatus & + & - & + & - & - \\
\hline C. nevadensis calidae & + & + & - & + & - \\
\hline C. sp. & + & + & - & - & - \\
\hline Empetrichthys latos concavus & + & + & - & - & - \\
\hline E. l. pahrump & + & + & - & - & - \\
\hline E. merriami & + & + & - & - & - \\
\hline Fundulus albolineatus & + & - & - & - & - \\
\hline Allotoca maculata & + & - & - & - & - \\
\hline Characodon garmani & + & - & - & - & - \\
\hline Gambusia amistadensis & + & - & - & + & - \\
\hline G. georgei & + & + & + & t & - \\
\hline Stizostedion vitreum glaucum & + & + & + & + & + \\
\hline Cottus echinatus & + & + & + & - & - \\
\hline
\end{tabular}

Trans. Proc. Ser. No. 3.

Cook, K. D. 1979. Fish population study of West Cache Creek with emphasis on search for the Wichita spotted bass, Micropterus punctulatus wichitae Proc. Okla. Acad. Sci. 59:1-3.

Day, D. 1981. The doomsday book of animals, a natural history of vanished species. Viking Press, New York. 288 pp.

Deacon, J. E., G. Kobetich, J. D. Williams, S. Contreras-Balderas, and others. 1979. Fishes of North America endangered, threatened or of special concern: 1979. Fisheries (Bethesda) 4(2):29-44.

Deason, H. J. 1936. Morphometric and life history studies of the pike-perches (Sti- zostedion) of Lake Erie. Doctoral dissertation. Univ. Michigan, Ann Arbor. 368 pp.

Diamond, J. M. 1987. Extant unless proven extinct? Or, extinct unless proven extant? J. Conserv. Biol. 1:77-79.

Edwards, R. J., H. E. Beaty, G. Longley, D. H. Riskind, D. D. Tupa, and B. G. Whiteside. 1984. The San Marcos recovery plan. U.S. Fish Wildl. Serv., Albuquerque, NM. 109 pp.

Evermann, B. W., and O. P. Jenkins. 1889 Notes on Indiana fishes. Proc. U.S. Natl. Mus. 11:43-57.

Gilbert, C. H. 1893 . Report on the fishes of the Death Valley expedition collected in southern California and Nevada in 1891 , with descriptions of new species. N. Am. Fauna 7:229-234.

Goldman, C. R., and R. G. Wetzel. 1963. A study of the primary productivity of Clear Lake, Lake County, California. Ecology 44:283-294.

Greene, W. S. 1937. Colorado trout. Denver Mus. Nat. Hist. Popular Ser. 2. 48 pp.

Heckmann, R. A., C. W. Thompson, and D. A. White. 1981. Fishes of Utah Lake. Great Basin Nat. Mem. 5:107-127.

Hopkirk, J. D. 1973. Endemism in fishes of the Clear Lake region. Univ. Calif. Publ. Zool. 96:1-160.

Hubbs, C. 1957. Distributional patterns of 
Appendix. Erroneously reported extinctions of fishes from North American waters. References indicate the first author or authors that listed the taxon as extinct. The Status shows the correct classification of the taxon as follows: $E=$ endangered, $T=$ threatened, $S C=$ of special concern as determined by Williams et al. 1989; $\mathrm{C}=$ common if the taxon was valid but not listed by Williams et al. 1989; $\mathrm{I}=$ invalid if it is not recognized as a valid taxonomic entity.

\begin{tabular}{|c|c|c|}
\hline Taxon & References & Status \\
\hline Greenback cutthroat trout, Oncorhynchus clarki stomias & Greene 1937 & $\mathrm{~T}$ \\
\hline San Gorgonio trout, O. evermanni & USDI 1966 & I \\
\hline Royal silver trout, O. mykiss regalis & La Rivers 1962 & I \\
\hline Emerald trout, O. m. smaragdus & La Rivers 1962 & I \\
\hline Saltillo roundnose minnow, Dionda episcopa punctifer & Day 1981 & I \\
\hline Clear Lake minnow, Endemichthys grandipinnis & Opler 1977 & I \\
\hline Summer Basin tui chub, Gila bicolor ssp. & ONHDB 1985 & $\mathrm{E}$ \\
\hline Big Spring spinedace, Lepidomeda mollispinis pratensis & Miller and Hubbs 1960 & $\mathrm{E}$ \\
\hline Blackmouth shiner, Notropis melanostomus & Layne 1976 & $\mathrm{~T}$ \\
\hline Rio Conchos sucker, Catostomus conchos & Contreras-Balderas 1978 & $\mathrm{~T}$ \\
\hline Shortnose sucker, Chasmistes brevirostris & Day 1981 & $\mathrm{E}$ \\
\hline Bigmouth lakesucker, $C$. stomias & Andreasen 1975 & I \\
\hline Dusky mountain sucker, Pantosteus sp. & Miller 1961 & I \\
\hline Smoky madtom, Noturus baileyi & Opler 1977 & $\mathrm{E}$ \\
\hline Yellowfin madtom, $N$. flavipinnis & Taylor 1969 & $\mathrm{~T}$ \\
\hline Leon Springs pupfish, Cyprinodon bovinus & Hubbs 1957 & $\mathrm{E}$ \\
\hline Shoshone pupfish, $C$. nevadensis shoshone & Pister 1974 & $\mathrm{E}$ \\
\hline Owens pupfish, C. radiosus & Miller 1961 & $\mathrm{E}$ \\
\hline Big Bend gambusia, Gambusia gaigei & Matthiessen 1959 & $\mathrm{E}$ \\
\hline Spring pygmy sunfish, Elassoma sp. & Ramsey 1976 & $\mathrm{~T}$ \\
\hline Wichita spotted bass, Micropterus punctulatus wichitae & Cook 1979 & $I$ \\
\hline Sharphead darter, Etheostoma acuticeps & Bailey and Richards 1963 & $\mathrm{SC}$ \\
\hline Trispot darter, E. trisella & Bailey and Richards 1963 & $\mathrm{~T}$ \\
\hline Snail darter, Percina tanasi & Robins et al. 1980 & $\mathrm{~T}$ \\
\hline Tilefish, Lopholatilus chamaeleonticeps & Lucas 1891 & $\mathrm{C}$ \\
\hline
\end{tabular}

Texas fresh-water fishes. Southwest. Nat. 2:89-104.

Hubbs, C., and B. L. Jensen. 1984. Extinction of Gambusia amistadensis, an endangered fish. Copeia 1984: 529-530.

Hubbs, C., and A. E. Peden. 1969. Gambusia georgei sp. nov. from San Marcos, Texas. Copeia 1969:357-364.

Hubbs, C. L. 1940. Fishes from the Big Bend region of Texas. Trans. Tex. Acad. Sci. 23:3-12.

Hubbs, C. L., and R. R. Miller. 1948. The zoological evidence: correlation between fish distribution and hydrographic history in the desert basins of western United States. Pages 17-166 in The Great Basin with emphasis on glacial and postglacial times. Bull. Univ. Utah. Vol. 38.

-. 1972. Diagnoses of new cyprinid fishes of isolated waters in the Great Basin of western North America. Trans. San Diego Soc. Nat. Hist. 17:101-106.

Hubbs, C. L., R. R. Miller, and L. C. Hubbs. 1974. Hydrographic history and relict fishes of the north-central Great Basin. Mem. Calif. Acad. Sci. 7:1-259.

Hunt, E. G., and A. I. Bischoff. 1960. Inimical effects on wildlife of periodic DDD application to Clear Lake. Calif. Fish Game 46:91-106.

Imlay, R. W. 1936. Evolution of the Coahuila Peninsula, Mexico. Part IV. Geology of the western part of the Sierra de Parras. Bull. Geol. Soc. Am. 47:1091-1152,

Johnson, J. E., and C. Hubbs. 1989. Status and conservation of poeciliid fishes. Pages 301-317 In G. Meffe and F. Snelson, eds. Ecology and evolution of livebearing fishes (Poeciliidae). Prentice Hall, New York.

Jordan, D. S. 1882. Report on the fishes of Ohio. Geol. Surv. Ohio 4:735-1002.

_- 1885. Note on Mr. Garman's paper on the American salmon and trout. Proc. U.S. Natl. Mus. 8:81-83.

__ 1890. Report of explorations made during the summer and autumn of 1888 , in the Allegheny Region of Virginia, North Carolina, Tennessee and in western Indiana, with an account of the fishes found in each of the river basins of those regions. Bull. U.S. Fish. Comm. 8:97-173.

—_. 1922. The days of a man, Vol. 1. World Books Co., New York. 710 pp.

Jordan, D. S., and B. W. Evermann. 18961900. The fishes of North and Middle America. Bull. U.S. Natl. Mus. 47:1-3313.

Jordan, D. S., and C. H. Gilbert. 1881. Notes on a collection of fishes from Utah Lake. Proc. U.S. Natl. Mus. 3 (for 1880): 459-465.

Juday, C. 1907. A study of Twin Lakes, Colorado, with special consideration of the food of the trouts. Bull. U.S. Bur.
Fish. 26:147-178.

Kan, T. T., and C. E. Bond. 1981. Notes on the biology of the Miller Lake lamprey, Lampetra (Entosphenus) minima. Northwest Sci. 55:70-74

Kendall, W. C. 1914. The fishes of New England. The salmon family. Part I: The trout or chars. Mem. Boston Soc. Nat. Hist. 8:103 pp.

Kirsch, P. H. 1896. A report upon investigations in the Maumee River basin during the summer of 1893. Bull. U.S. Fish Comm. 14:315-334.

Koelz, W. 1929. Coregonid fishes of the Great Lakes. Bull. U.S. Bur. Fish. 43 (for 1927):297-643.

La Rivers, I. 1962. Fishes and fisheries of Nevada. Nevada State Fish and Game Comm. 782 pp

Lanteigne, J. 1988. Status of the Banff longnose dace, Rhinichthys cataractae smithi, in Canada. Can. Field-Nat. 102:170-176.

Layne, J. N., ed. 1976. Inventory of rare and endangered biota of Florida. Fla. Audubon Soc. and Fla. Defenders Environ. $1152 \mathrm{pp}$.

Lucas, F. A. 1891. Animals recently extinct or threatened with extermination, as represented in the collections of the U.S. National Museum. Rept. U.S. Natl. Mus. 1888-1889. 41 pp.

Matthews, W. J. 1987. Geographic variation 
in Cyprinella lutrensis (Pisces: Cyprinidae) in the United States, with notes on Cyprinella lepida. Copeia 1987:616637.

Matthiessen, P. 1959. Wildlife in America. The Viking Press, New York. 304 pp.

McAllister, D. E., B. J. Parker, and P. M. McKee. 1985. Rare, endangered, and extinct fishes in Canada. Syllogeus 54. Natl. Mus. of Nat. Sci., Ottawa, Ontario. 192 pp.

Miller, R. J., and H. E. Evans. 1965. External morphology of the brain and lips in catostomid fishes. Copeia 1965:467-487.

Miller, R. R. 1948. The cyprinodont fishes of the Death Valley system of eastern California and southwestern Nevada. Misc. Publ. Mus. Zool. Univ. Mich. 68:1155.

1961. Man and the changing fish fauna of the American Southwest. Pap. Mich. Acad. Sci. Arts. Lett. 46:365-404.

1963. Synonymy, characters, and variation of Gila crassicauda, a rare Californian minnow, with an account of its hybridization with Lavinia exilicauda. Calif. Fish Game 49:20-29.

1984. Rhinichthys deaconi, a new species of dace (Pisces: Cyprinidae) from southern Nevada. Occas. Pap. Mus. Zool. Univ. Mich. 707:1-21.

Miller, R. R., and C. L. Hubbs. 1960 . The spiny-rayed cyprinid fishes (Plagopterini) of the Colorado River system. Misc. Publ. Mus. Zool. Univ. Mich. 115:1-39.

Miller, R. R., and E. P. Pister. 1971. Management of the Owens pupfish, Cyprinodon radiosus, in Mono County, California. Trans. Am. Fish. Soc. 100:502-509.

Miller, R. R., and G. R. Smith. 1981. Distribution and evolution of Chasmistes (Pisces: Catostomidae) in western North America. Occas. Pap. Mus. Zool. Univ. Mich. 696:1-46.

Mills, T. J., and K. A. Mamika. 1980. The thicktail chub, Gila crassicauda, an extinct California fish. Calif. Dep. Fish Game, Inland Fish. End. Sp. Prog. Spec. Publ. 80-2. 21 pp.

Minckley, W. L. 1973. Fishes of Arizona. Ariz. Game Fish Dep. 293 pp.

Moyle, P. B. 1976. Inland Fishes of California. Univ. Calif. Press, Berkeley. 405 pp.

Murphy, G. 1. 1951. The fishery of Clear Lake, Lake County, California. Calif. Fish Game 37:439-484.

Opler, P. A. 1977. The parade of passing species: a survey of extinctions in the U.S. Sci. Teacher Vol. 44. 5 pp.

ONHDB (Oregon Natural Heritage Data Base). 1985. Rare, threatened and endangered plants and animals of Oregon. The Nature Conservancy, Portland, OR. 31 pp.

Peden, A. E. 1973. Virtual extinction of Gambusia amistadensis n. sp., a poeciliid fish from Texas. Copeia 1973:210-221.
Pister, E. P. 1974. Desert fishes and their habitats. Trans. Am. Fish. Soc. 103:531540.

Pritchard, A. L. 1931. Taxonomic and life history studies of the ciscoes of Lake Ontario. Univ. Toronto Stud., Biol. Ser. 25, Publ. Ontario Fish. Res. Lab. 41. 78 pp.

Ramsey, J. S. 1976. Freshwater fishes. Pages 53-65 in Endangered and threatened plants and animals of Alabama. Bull. Ala. Mus. Nat. Hist. No. 2.

Regier, H. A., V. C. Applegate, and R. A. Ryder. 1969. The ecology and management of the walleye in western Lake Erie. Great Lakes Fish. Comm. Tech. Rept. 15. 101 pp.

Renaud, C. B., and D. E. McAllister. 1988. Taxonomic status of the extinct Banff longnose dace, Rhinichthys cataractae smithi, of Banff National Park, Alberta. Environ. Biol. Fishes 23:95-113.

Robins, C. R., R. M. Bailey, C. E. Bond, J. R. Brooker, E. A. Lachner, R. N. Lea, and W. B. Scott. 1980. A list of common and scientific names of fishes from the United States and Canada, 4th ed. Am. Fish. Soc. Spec. Publ. No. 12. 174 pp.

Rutter C. 1908. The fishes of the SacramentoSan Joaquin basin, with a study of their distribution and variation. Bull. U.S. Bur. Fish. 27 (for 1907): 103-152.

Schulz, P. D. 1979. Fish remains from a historic central California Indian village. Calif. Fish Game 65:273-276.

Scott, W. B., and S. H Smith. 1962. The occurrence of the longjaw cisco, Leucichthys alpenae, in Lake Erie. J. Fish. Res. Board Can. 19:1013-1023.

Smith, M. L., and R. R. Miller. 1980. Allotoca maculata, a new species of goodeid fish from western Mexico, with comments on Allotoca dugesi. Copeia 1980:408-417.

- 1986. Mexican goodeid fishes of the genus Characodon, with description of a new species. Am. Mus. Novit. 2851: $1-14$.

Smith, S. H. 1964. Status of the deepwater cisco population of Lake Michigan. Trans. Am. Fish. Soc. 93(2):155-163.

_- 1968. Species succession and fishery exploitation in the Great Lakes. J. Fish. Res. Board Can. 25:667-693.

1970. Trends in fishery management of the Great Lakes. Pages 107-114 in N. G. Benson, ed. A century of fisheries in North America. Am. Fish. Soc. Spec. Publ. 7. Bethesda, MD.

Sokol, O. 1954. To the desert for fishes. Aquarium J. 25:178-182.

Tanner, V. M. 1936. A study of the fishes of Utah. Utah Acad. Sci. Arts. Lett. 13: 155-183.

Taylor, F. R., R. R. Miller, J. W. Pedretti, and J. E. Deacon. 1988. Rediscovery of the Shoshone pupfish, Cyprinodon nevadensis shoshone (Cyprinodontidae), at
Shoshone Springs, Inyo County, California. Bull. South. Calif. Acad. Sci. 87:6773.

Taylor, W. R. 1969. A revision of the catfish genus Noturus Rafinesque, with an analysis of higher groups in the Ictaluridae. Bull. U.S. Natl. Mus. 282:1-315.

Tol, D., and J. French. 1988. Status of a hybridized population of Alvord cutthroat trout from Virgin Creek, Nevada. Pages 116-120 in R. E. Gresswell, ed. Status and management of interior stocks of cutthroat trout. Am. Fish. Soc. Symp. 4, Bethesda, MD.

USDI (U.S. Department of the Interior). 1966. Rare and endangered wildlife of the United States. U.S. Fish WildI. Serv. Resour. Publ. 34. $157+$ pp.

1989. Endangered and threatened wildlife and plants. Title 50, Code of Federal Regulations 17.11 and 17.12, 1 January 1989. U.S. Fish and Wildlife Service, Washington, DC. $34 \mathrm{pp}$

Vinyard, G. 1984. A status report about the Independence Valley speckled dace (Rhinichthys osculus lethoporus), Independence Valley tui chub (Gila bicolor isolata) and Clover Valley speckled dace (Rhinichthys osculus oligoporus); three fishes restricted to the northeastern portion of Nevada. Status Rept. to U.S. Fish Wildl. Serv., Reno, NV. 21 pp.

Warfel, H. E., C. V. MacCoy, and L. E. Foote. 1939. Notes on lakes of the Connecticut watershed. Pages 88-121 in $\mathrm{H}$. E. Warfel, ed. Biological survey of the Connecticut watershed. New Hampshire Fish and Game Dep. Surv. Rept. 4:1-256.

Williams, J. E., and C. E. Bond. 1983. Status and life history notes on the native fishes of the Alvord Basin, Oregon and Nevada. Great Basin Nat. 43:409-420.

Williams, J. E., D. B. Bowman, J. E. Brooks, A. A. Echelle, R. J. Edwards, D. A. Hendrickson, and J. J. Landye. 1985. Endangered aquatic ecosystems in North American deserts with a list of vanishing fishes of the region. J. Ariz-Nev. Acad. Sci. 20:1-62.

Williams, J. E., J. E. Johnson, D. A. Hendrickson, S. Contreras-Balderas, J. D. Williams, M. Navarro-Mendoza, D. E. McAllister, and J. E. Deacon. 1989. Fishes of North America endangered, threatened, or of special concern: 1989. Fisheries (Bethesda) 14(6):2-20.

Wilson, E. O. 1988. The current state of biological diversity. Pages 3-18 in E. O. Wilson, ed. Biodiversity. National Academy Press, Washington, DC.

Woolman, A. J. 1892. Report of an examination of the rivers of Kentucky with lists of the fishes obtained. Bull. U.S. Fish Comm. 10:249-289.

1895. Report on a collection of fishes from the rivers of central and northern Mexico. Bull. U.S. Fish Comm. 14:55-66. 